\title{
Soil erosion and land-use change during the last six millennia recorded in lake sediments of Gudme Sø, Fyn, Denmark
}

\author{
Peter Rasmussen and Jesper Olsen
}

The Danish landscape is characterised by low relief and consequently the risk of soil erosion is low compared to many central and southern European countries with more variable terrain (European Environment Agency 2000; Van der Knijff et al. 2000). However, even in countries with less intensive erosion, water-induced soil erosion is recognised as an increasingly important environmental issue due to its role in the transport of nutrients, pesticides and other contaminants to rivers, lakes and coastal waters (e.g. Stone 2000).

There are relatively few monitoring programmes of sediment erosion in Denmark and those that exist typically only cover the last few decades (Veihe et al. 2003). Therefore, it is difficult to identify long-term trends and baseline conditions. However, the geological record provides insight into patterns and rates of soil erosion through time. Lake and fjord sediment archives are especially useful because they can provide continuous and undisturbed sediment successions that can be analysed at high temporal resolution. These sediment records can be examined using a variety of approaches that include sedimentological, geochemical and biological analyses and thus generate important insight into baseline states, trajectories and responses to forcing mechanisms over long timescales, which would otherwise be difficult to obtain. The records are typically limited to yielding insight only into the average rate of erosion and they often provide little information about the spatial extent or distribution of erosional processes within a catchment area.

In this paper we present an example of a long-term erosional record from Gudme Sø, Fyn (Fig. 1). Numerous archaeological excavations have been undertaken near Gudme $S_{\varnothing}$, and the Geological Survey of Denmark and Greenland has carried out analyses of sediments from the lake to provide a continuous picture of landscape changes. Sediment accumulation rates of minerogenic matter and pollen analysis are here used to explore the erosional response to changes in land-use.

\section{Study site and methods}

Gudme Sø is located on south-east Fyn $c .5 \mathrm{~km}$ from the sea in a gently undulating terrain with surface deposits consisting of clay till (Fig. 1). The lake has a surface area of 9 ha, a mean water depth of $0.5 \mathrm{~m}$, and a catchment area of 48 ha.
It has no major natural inlets or outlets. An $11.8 \mathrm{~m}$ long sediment core of slightly humic gyttja with low calcareous content and varying silt and clay contents was retrieved from the lake. Age determination was provided by radiocarbon dating, and the chronology at the top of the core was further refined by linear interpolation, using the first occurrence of spheroidal carbonaceous fly-ash particles and the date of the sediment surface (i.e. the year of coring) as bracketing ages (Fig. 2).

Sediment accumulation rates of minerogenic matter (SAR-min in $\mathrm{mg} / \mathrm{cm}^{2}$ per year) were calculated and used as proxies of soil erosion from the catchment area to the lake (e.g. Mackereth 1966). The changes in SAR-min values were compared to pollen-inferred changes in vegetation and landuse from the same sediment core. The increases and decreases in non-arboreal pollen (NAP) were used as a record of changes in the proportion of open land. It is assumed that the variation in the sum of taxa of cultivated plants and Plantago lanceolata (ribwort plantain) reflects changes in the extent of arable land, and pastures or meadows, respectively (Behre 1981; Gaillard 2007). The record of colonies of the green algae Pediastrum sp. is used as proxy evidence for in-lake productivity (Bradshaw et al. 2005).

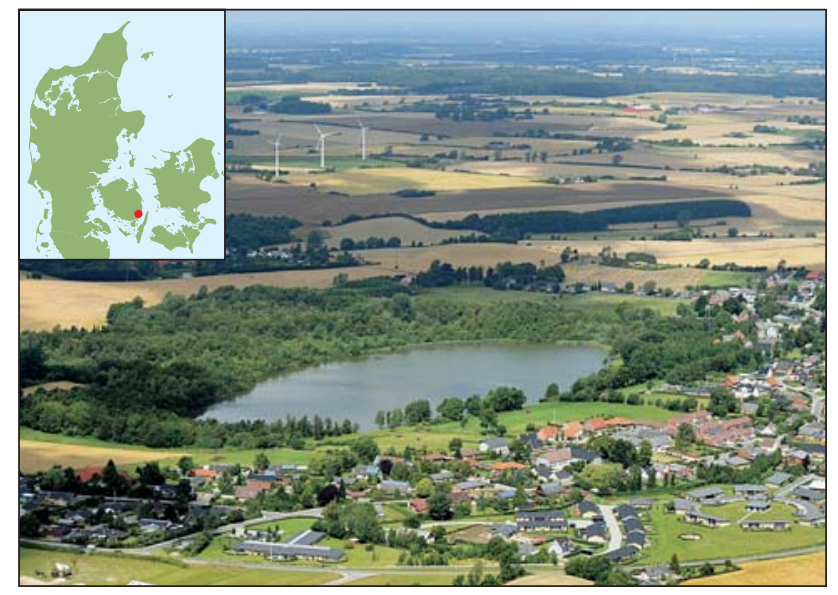

Fig. 1. Aerial photograph of Gudme Sø seen from the south-east. The lake size is c. $490 \times 250 \mathrm{~m}$. Today the lake catchment area (48 ha) consists of $50 \%$ tilled, $25.8 \%$ natural and $24.2 \%$ built-up area. Photograph courtesy of The Royal Danish Air Force. 


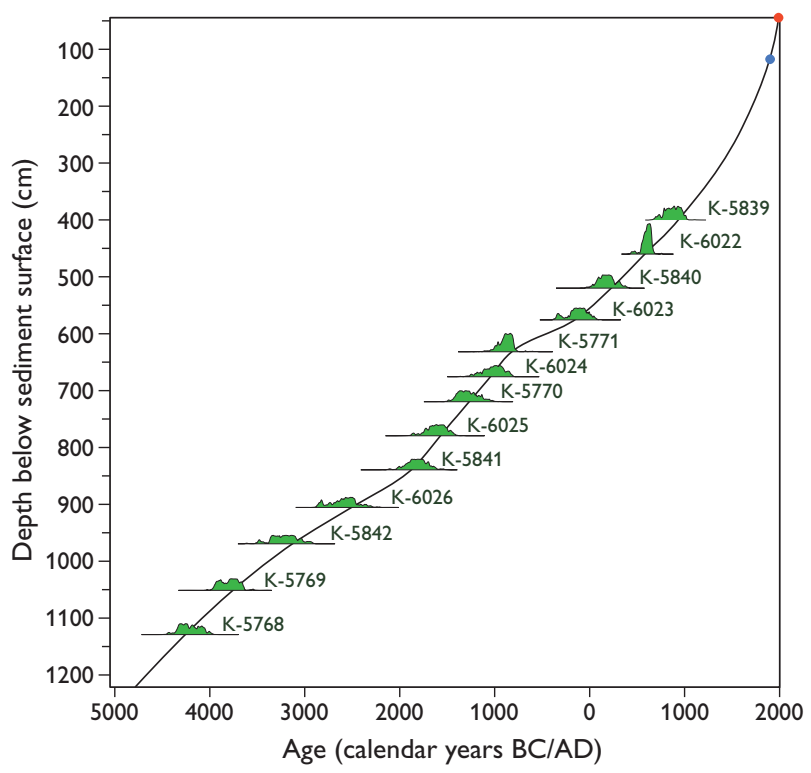

Fig. 2. Age-depth model for the Gudme Sø sediment succession based on 13 calibrated ${ }^{14} \mathrm{C}$ dates, the date of the first occurrence of spheroidal carbonaceous fly-ash particles (blue dot at AD 1900; Odgaard 1993) and the age of the sediment surface (red dot at AD 1989). The K-numbers are the laboratory numbers for the dated samples. The small diagrams show probability distributions of the calibrated ages. The age-depth model was established using the programme Bpeat (Blaauw \& Christen 2005).

\section{Results and discussion}

\section{Chronology}

The ${ }^{14} \mathrm{C}$ dates from the Gudme Sø sediment core are based on bulk sediment samples and may overestimate their actual ages due to the hard-water effect (Björck \& Wohlfarth 2001). However, the $\mathrm{CaCO}_{3}$ content of the sediments is very low and the ages of key-pollen, stratigraphical levels at Gudme $S_{\varnothing}$ are in agreement with other independent ages from corresponding levels in Danish bogs where the dated peat is unaffected by hard water (Table 1). Hence, we consider the Gudme Sø age-depth model to be reasonably accurate and reliable within $c .100$ years. In the following, all ages are given in calendar years $\mathrm{BC} / \mathrm{AD}$.

\section{Incipient landscape disturbance}

In Fig. 3 the history of the last c. 6000 years of soil erosion to the Gudme Sø basin is compared with contemporary changes in vegetation and land-use. Coincident increases in total NAP and taxa of cultivated plants and in SAR-min suggest a causal link between agricultural activities and soil loss.

The low SAR-min values in the late Mesolithic (c. 42003900 BC) suggest a low level of soil disturbance, which is in good agreement with the pollen data. Very low NAP values (c. 2\%) indicate that the landscape was dominated by closedcanopy forests with only a sparse field layer vegetation (Iversen 1973). During the Mesolithic, anthropogenic impact on the vegetation appears to have been negligible, and landscape disturbance was driven by natural agencies, implying that the sediment flux to the lake at this time represents a 'natural' baseline state.

In Denmark the cultural shift from the Mesolithic (hunting-fishing-gathering) to the Neolithic (farming) way of living took place $c .3900 \mathrm{BC}$. Approximately 200 years later (c. 3650-3500 BC) a marked increase in both SAR-min and NAP values at Gudme Sø indicate an erosional event clearly triggered by deforestation that was associated with incipient agricultural activities. At that time the first pollen types unambiguously indicative of crop cultivation and pastoral farming occurred (cereals and Plantago lanceolata, respectively). Interestingly, the data indicate that catchment disturbance and agricultural activities precede accelerated erosion rates by c. 150-200 years, thus showing a delay or threshold effect in the system's response.

Between c. 3350 and $3200 \mathrm{BC}$ soil erosion rates increased again, although this time not correlated with pollen evidence of land clearance or intensified agriculture. Low soil erosion rates between c. 3200 and $2650 \mathrm{BC}$ and low NAP values indicate catchment stability. At about $2650 \mathrm{BC}$ a renewed and short-lived (c. 2650-2550 BC) deforestation was accompanied by intensified agricultural activities reflected in high percentages of NAP, Plantago lanceolata and cultivated taxa. Despite the apparent intensity of this brief land clearance episode, the erosional response was moderate. This might be

Table $1 .{ }^{14} \mathrm{C}$ dates of pollen-analytical levels in Gudme Sø and three Danish raised bogs

\begin{tabular}{|c|c|c|c|c|}
\hline & $\begin{array}{c}\text { Gudme } \\
\text { Sø }\end{array}$ & $\begin{array}{l}\text { Fuglsø } \\
\text { Mose }\end{array}$ & $\begin{array}{l}\text { Abkær } \\
\text { Mose }\end{array}$ & $\begin{array}{l}\text { Holmegaard } \\
\text { Mose }\end{array}$ \\
\hline 1st Centaurea cyanus (cornflower) & AD 1320 & AD 1360 & AD 1240 & AD 1350 \\
\hline 1st Secale cereale (rye) & $170 \mathrm{BC}$ & $80 \mathrm{BC}$ & $80 \mathrm{BC}$ & $80 \mathrm{BC}$ \\
\hline Fagus sylvatica (beech) 3-5\% & $960 \mathrm{BC}$ & $890 \mathrm{BC}$ & $240 \mathrm{BC}$ & $920 \mathrm{BC}$ \\
\hline Fagus sylvatica $($ beech) $>0.5-1 \%$ & $1460 \mathrm{BC}$ & $1320 \mathrm{BC}$ & $1320 \mathrm{BC}$ & $1400 \mathrm{BC}$ \\
\hline 1st Plantago lanceolata (ribwort plantain) & $3650 \mathrm{BC}$ & $3630 \mathrm{BC}$ & $3000 \mathrm{BC}$ & $3800 \mathrm{BC}$ \\
\hline Elm decline & $3990 \mathrm{BC}$ & $3830 \mathrm{BC}$ & $3870 \mathrm{BC}$ & $3500 \mathrm{BC}$ \\
\hline
\end{tabular}

Data partly from Odgaard (1994). 
Fig. 3. A: Sediment accumulation rate of minerogenic matter (SAR-min; proxy of soil erosion rate) and non-arboreal pollen (NAP; proxy for open land). The results of the pollen analysis are presented as percentages of the total sum of pollen and spores from terrestrial plants. B: Pollen percentages of the sum of cultivated taxa. C: Pollen percentages of Plantago lanceolata (ribwort plantain). D: Percentages of the green algae Pediastrum sp. (calculated on the basis of the terrestrial pollen and spore sum). For B, C and D the dark-coloured curves are percentages and the light-coloured areas represent 10 times exaggeration.

due to the type of land-use at a time when subsistence economy most likely was predominantly based on pastoral farming. In contrast to arable farming, such land-use implies the maintenance of permanently grass-covered pasture that would be less prone to erosion than cultivated fields (Veihe et al. 2003). After $2550 \mathrm{BC}$, low soil erosion rates indicate a long period of relative stability in the catchment area, which lasted until the middle of the Bronze Age at $c .1000 \mathrm{BC}$.

\section{Landscape transformation}

For $c$. 150 years, between 1000 and 850 BC, the landscape around Gudme Sø changed drastically and became far more open than previously as suggested by the increase in NAP. Extensive forest clearance and expansion of areas used for livestock grazing and crop cultivation led to comprehensive landscape disturbance and a marked increase in erosion rates to the lake. The contemporary increase in Pediastrum sp. indicates a larger nutrient loss from the catchment area to the lake due to soil in-wash, which enhanced the in-lake productivity. After c. 200 years, the sediment influx to the lake gradually declined and stabilised, despite a continued high anthropogenic impact on the landscape as indicated by the continued high NAP values.

In the Iron Age around $100 \mathrm{BC}$, the erosion rates increased slightly and remained almost constant until $c$. AD 400. Thereafter, there was a short-lived disturbance period around $\mathrm{AD}$ 400-500 with intensified arable farming (increased abundances of cultivated taxa), accelerated soil erosion, and higher lake productivity (raised percentages of Pediastrum sp.). High percentages of Cannabis-type pollen in this period (not shown) indicate that the lake was used for
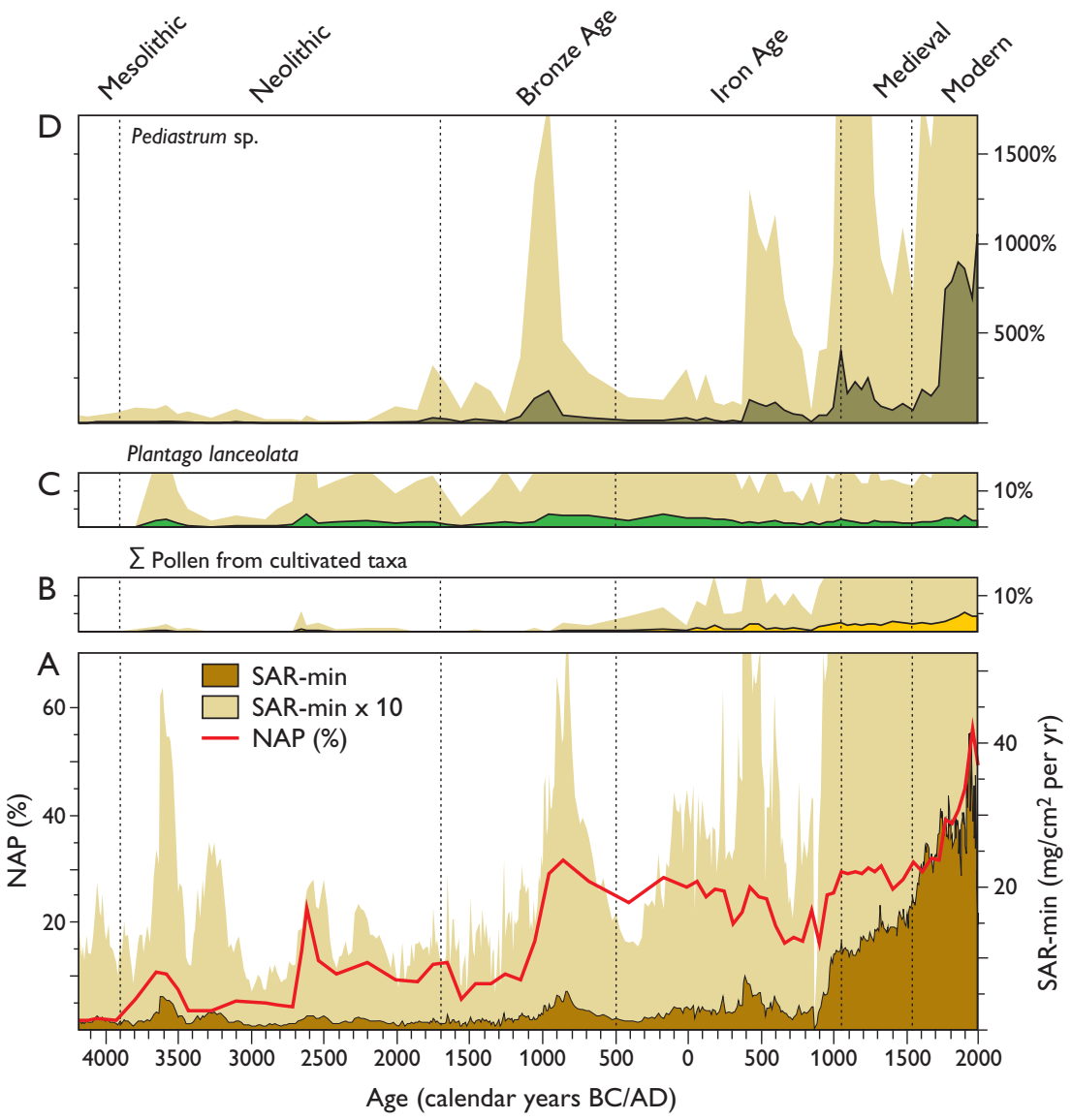

retting hemp, a process in which stems are soaked in water to free their bast fibres from the surrounding tissue in order to produce fibres for example for cloth and rope making. Hemp-retting in the lake most likely contributed to the increased input of minerogenic material, as plants for retting may have been placed in the lake with roots; this could also have contributed to the nutrient enrichment of the lake at that time (Odgaard 1994).

Between $c$. AD 600 and 900 the soil erosion rate to the lake decreased, in agreement with the reduced anthropogenic impact on the landscape as reflected in the decreasing NAP values. At this time, the use of the lake for hemp-retting almost ceased and the percentage value of Pediastrum sp. declined. Between AD 950 and 1050, i.e. in the second half of the Viking Age, the pollen data suggest renewed deforestation followed by greatly intensified arable farming (elevated percentages of cultivated taxa). This marked change in landuse led to an unprecedented increase in soil erosion that likely caused eutrophication of the lake involving blooms of Pediastrum sp. The nutrient enrichment of the lake may have been further intensified by resumption of hemp-retting in the lake, a procedure which continued to around AD 1900.

During the Medieval period, the anthropogenic impact on the landscape increased significantly as land clearance in- 
creased and crop cultivation intensified. The cultivation of large new areas was facilitated by the introduction of new farming technology such as the mouldboard plough and ridge-and-furrow. At Gudme Sø, the intensive arable farming in the Middle Ages led to steadily increasing sediment yields. The abundance of Pediastrum sp. at this time suggests continued eutrophication.

In Modern time (AD 1536 to the Present) the area around the lake was further cultivated at the expense of woodland. From c. AD 1500 to 1950, NAP values increased from c. 30\% to $55 \%$ indicating widespread agricultural activities predominantly characterised by crop cultivation. The high and increasing human impact during this period corresponds closely to a dramatic and unprecedented increase in soil erosion, which peaked around AD 1950 contemporaneously with the highest NAP values in the entire record. A rapid and marked increase in the percentage of Pediastrum sp. at the beginning of the 18th century signifies the onset of a major nutrient enrichment of the lake.

\section{Concluding remarks}

The investigation of the lake sediments from Gudme Sø provides a 6000-year-record of soil erosion rates as well as contemporary pollen-inferred changes in vegetation and land-use. The study demonstrates a close correlation between changes in agricultural activity and rates of soil erosion in the catchment area of the lake. Prior to the late Viking Age, erosion to the lake occurred in pulses triggered by episodes of land clearance followed by periods of relative stability in the catchment area. After the late Viking Age, soil erosion accelerated continuously and reached a peak in the mid-20th century with erosion rates approximately 30 times higher than the pre-disturbance rates in the Mesolithic. The study demonstrates that after the introduction of agriculture, soil erosion was mainly caused by human activity rather than climate. This general result has also emerged from other lake-based studies of long-term erosion in Denmark (Rasmussen \& Bradshaw 2005) and southern Sweden (Dearing 1991). According to current climate models we can expect an increase in precipitation, more rainfall in the winter season and a higher frequency of extreme precipitation events in the future (Christensen et al. 2006). Given these predictions, climate will undoubtedly be of growing significance as a forcing mechanism for soil erosion.

\section{Acknowledgement}

The Gudme Sø investigation is part of an archaeological research project funded by A.P. Møller og Hustru Chastine Mc-Kinney Møllers Fond til almene Formaal.

\section{References}

Behre, K.-E. 1981: The interpretation of anthropogenic indicators in pollen diagrams. Pollen et Spores 23, 225-245.

Björck, S. \& Wohlfarth, B. 2001: ${ }^{14} \mathrm{C}$ chronostratigraphic techniques in paleolimnology. In: Last, W.M. \& Smol, J.P. (eds): Tracking environmental change using lake sediments: basin analysis, coring, and chronological techniques 1, 205-245.

Blaauw, M. \& Christen, J.A. 2005: Radiocarbon peat chronologies and environmental change. Journal of the Royal Statistical Society, Series C (Applied Statistics) 54, 805-816.

Bradshaw, E.G., Rasmussen, P., Nielsen, H. \& Anderson, N.J. 2005: Midto late-Holocene land-use change and lake development at Dallund $S \varnothing$, Denmark: trends in lake primary production as reflected by algal and macrophyte remains. The Holocene 15, 1130-1142.

Christensen, J.H., Christensen, O.B., Guldberg, A. \& Stendel, M. 2006: Modeller for klimaets udvikling. In: Søndergaard, M., Kronvang, B., Pejrup, M. \& Sand-Jensen, K. (eds): Vand og vejr om 100 år - klimaforandringer og det danske vandmiljø, 40-54. Højbjerg: Forlaget Hovedland.

Dearing, J.A. 1991: Erosion and land use. In: Berglund, B.E. (ed.): The cultural landscape during 6000 years in southern Sweden. Ecological Bulletins 41, 283-292

European Environment Agency 2000: Down to earth: soil degradation and sustainable development in Europe. A challenge for the 21st century. Environmental Issue Series 16, $32 \mathrm{pp}$. Luxembourg: Office for Official Publications of the European Communities.

Gaillard, M.-J. 2007: Pollen methods and studies - Archaeological applications. In: Elias, S.A. (ed.): Encyclopedia of Quaternary science 3, 2570-2595. Oxford: Elsevier Science.

Iversen, J. 1973: The development of Denmark's nature since the last glacial. Danmarks Geologiske Undersøgelse V. Række 7-C, 126 pp.

Mackereth, F.J.H. 1966: Some chemical observations on post-glacial lake sediments. Philosophical Transactions of the Royal Society of London, Series B, 250, 165-213.

Odgaard, B.V. 1993: The sedimentary record of spheroidal carbonaceous fly-ash particles in shallow Danish lakes. Journal of Paleolimnology $\mathbf{8}$, 171-187.

Odgaard, B.V. 1994: The Holocene vegetation history of northern West Jutland, Denmark. Opera Botanica 123, $171 \mathrm{pp}$.

Rasmussen, P. \& Bradshaw, E. 2005: Mid- to late-Holocene land-use change and lake development at Dallund $\varsigma \varnothing$, Denmark: study aims, natural and cultural setting, chronology and soil erosion history. The Holocene 15, 1105-1115.

Stone, M. (ed.) 2000: The role of erosion and sediment transport in nutrient and contaminant transfer. International Association of Hydrological Sciences Publication 263, 308 pp.

Van der Knijff, J.M., Jones, R.J.A. \& Montanarella, L. 2000: Soil erosion risk assessment in Europe, 34 pp. EUR 19044 EN. Ispra: European Soil Bureau, Joint Research Centre and Space Applications Institute.

Veihe, A., Hasholt, B. \& Schiøtz, I.G. 2003: Soil erosion in Denmark: processes and politics. Environmental Science \& Policy 6, 37-50.

\footnotetext{
Authors' addresses

P.R., Geological Survey of Denmark and Greenland, Øster Voldgade 10, DK-1350 Copenhagen K, Denmark. E-mail: per@geus.dk

J.O., Department of Earth Sciences, Aarbus University, Høegh-Guldbergs Gade 2, DK-8000 Århus C, Denmark.
} 